\title{
1. Early Cinema, Process Films, and Screen Advertising
}

\author{
Yvonne Zimmermann
}

\begin{abstract}
This chapter explores what early process films can tell us about advertising and the transformation of screen cultures. Starting with a detailed historical study of an exemplary process film, the chapter addresses a number of conceptual issues that resonate with takes on screen advertising suggested in the present book. A particular focus lies on screen advertising's entanglement with entertainment culture, education, visual culture, and commodity culture. Questions of genre and aesthetics, in particular the colour aesthetics of process films in early cinema as well as their colonialist ideology, are also addressed. The chapter argues that screen advertising, despite its often-acknowledged ephemeral nature, is an utterly robust or persistent phenomenon - persistent in regard to the objects, screens, and practices of screen advertising.
\end{abstract}

Keywords: early cinema, process film, advertising, colour, colonial visual culture

It is 1909, a sunny spring day in Bernese Oberland; cherry trees are in blossom and cows leave the barn, driven by cowherds dressed in traditional local costumes. ${ }^{1}$ Cowbells in bronze try to outshine the cherry blossom tree and the marvellous mountain scenery. Two calves strain at the leash in youthful zeal under the eyes of a prudent Bernese mountain dog. A horizontal pan across the alpine pasture reveals the substantial size of the herd, the stately

1 I dedicate this chapter to my father, who was a committed Swiss cheesemaker, an ardent admirer of free jazz, and a cinephile. I suspect he would not have loved the films I write about - but perhaps I am wrong.

Florin, B., P. Vonderau, Y. Zimmermann, Advertising and the Transformation of Screen Cultures. Amsterdam: Amsterdam University Press, 2021 DOI 10.5117/9789462989153_CHO1 
farmhouse, and the well-maintained agricultural buildings. Then it is time for the cows to be milked and for the cowherds to carry the precious white liquid in traditional wooden containers on their backs down to the valley.

This 'dispatch to the factory' (title card; my translation) marks a switch in location and in work procedure; it is a shift from the alp to the factory and from a pre-industrial, artisanal extraction of raw material to the industrial processing of it into condensed milk. And it is, surely not by chance, the moment for the company name to make an entrance: BAMG (Berner Alpenmilchgesellschaft / Bernese Alps Milk Company). 'Stalden' is easily legible on the horse-drawn carriages fully loaded with milk cans that drive past the camera in a diagonal angle towards the factory located in the vanishing point.

The film Milcherzeugung in der Schweiz / Préparation et exportation du lait par la Sté Laitière des Alpes Bernoises (Milk Production in Switzerland) is a typical example of what scholars retrospectively have termed 'process film[s]' in early cinema. ${ }^{2}$ Produced by Pathé Frères, the film depicts, step by step, the transformation of raw milk into a consumable good, that is, into canned condensed milk. Following the pastoral overture in the Swiss mountains, the industrial production process is presented in a factual mode with title cards explaining the pasteurization and condensation of the milk in great detail: 'The milk is heated to 100 degrees Celsius, mixed with six per cent sugar, and reduced in volume by half through evaporation of its liquid content.' It goes on: 'The milk is filled in tin cans or bottles, which are put into a water bath for the purpose of sterilization.' The images offer glimpses into all production departments that are involved in the process, from the laboratory and production department to the packing and shipping department. The packing and shipping shots allow for the inclusion of cans, shipping cases, and wall posters that are labelled with the company name and/or the brand name, the 'Bear Brand', and its logo, a brown bear sitting on its back, holding a white baby bottle. In this way, the film brands factual information, thus following a promotional strategy that could be termed branded education and that in today's Tv advertising practice is called an infomercial. At the same time, Milcherzeugung in der Schweiz can also be considered an early form of branded entertainment, for the visual pleasure it provides, especially in the opening scenes that are lavishly stencil coloured (an aspect I will come back to later on). Following Jay Newell, Charles T. Salmon, and Susan Chang, who define product placement, also known as tie-in or tie-up, as 'the insertion of branded products or services into mass

2 A 35 mm print of Milcherzeugung in der Schweiz is preserved at the Bundesarchiv-Filmarchiv Berlin. Unfortunately, to this date, the film is not available online or on DVD. 

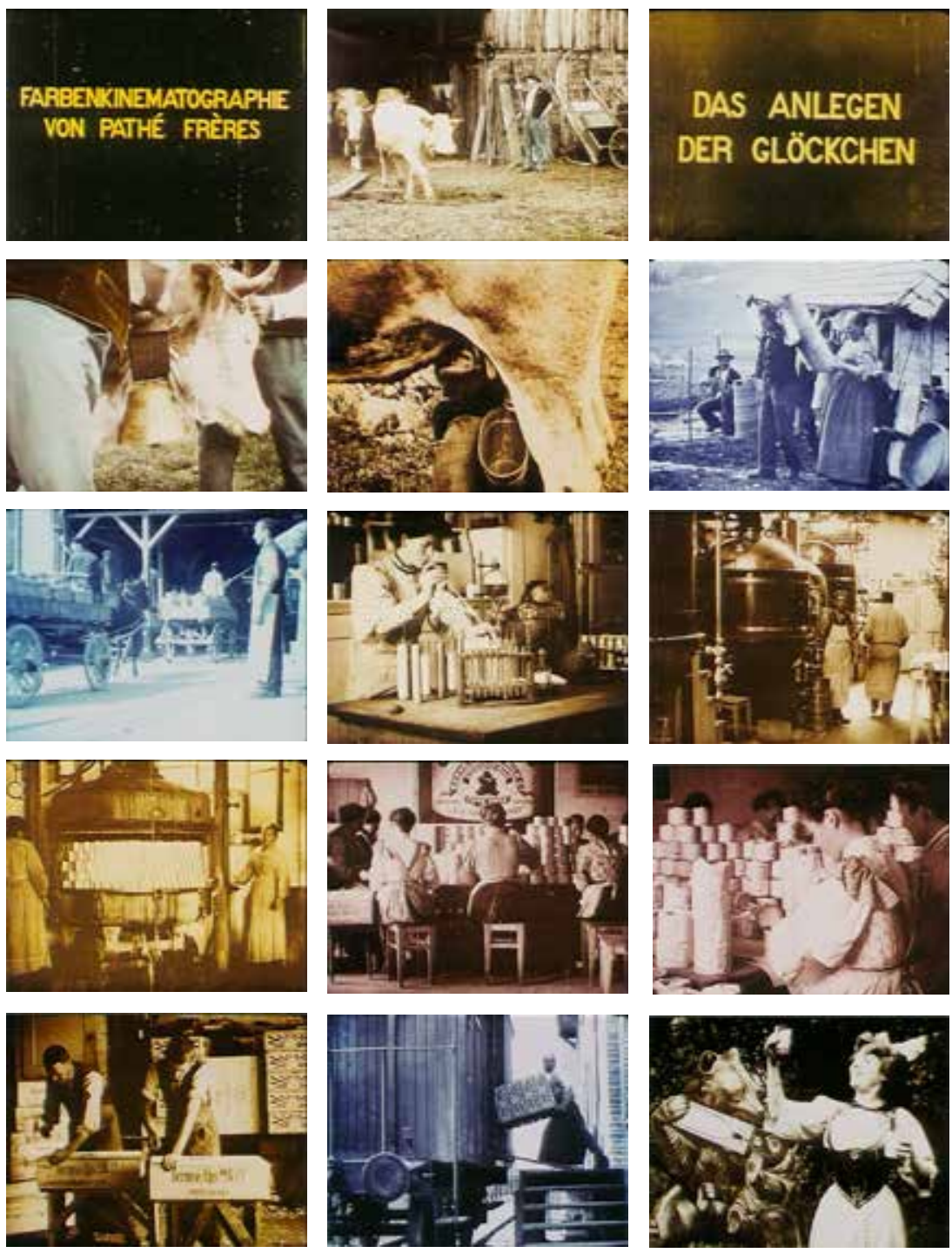

Figures 1.1-1.15: Screenshots from Milcherzeugung in der Schweiz (Pathé Frères, 1910). 
media content with the intent of influencing consumer attitude or behaviour', the presence of the 'Bear Brand' also qualifies as product placement. ${ }^{3}$

The last scene of the film is dedicated to 'The tasting' (title card) and yet again provides a shift in audience address. It switches from an instructional mode of address and an overall gesture of showing and displaying to address the audience directly and in an appellative way as is typical for 'outright' advertising: next to a cardboard mother bear giving her baby a bottle stands a young woman in costume who raises the glass of condensed milk she is tasting to the audience and, with sweeping gestures and a big smile, gives animated testimony to the tastiness of the product. In this way, the film ends on a humorous note. Milcherzeugung in der Schweiz uses astonishment and awe to attract viewers' attention for the instructional and promotional parts, then rewards spectators for staying with the film by giving them a good laugh at the end.

In this opening essay, I explore what early process films can tell us about advertising and the transformation of screen cultures and in what ways they can be instructive in thinking about how to conceptualize screen advertising from the point of view of cinema and media studies. I do this on the basis of a detailed historical consideration of a single object - an exemplary process film - in context, with the aim to address a number of conceptual issues that resonate with perspectives on screen advertising suggested in the essays in the present book. Thereby, facets like the place of moving image advertising in media programmes and in institutions surface, the latter leading here to considerations of screen advertising's entanglement with entertainment culture, education, visual culture, and commodity culture. Questions of genre and aesthetics, in particular the colour aesthetics of process films in early cinema as well as their colonialist ideology, are also addressed. The overall argument that runs through this essay, though, is that screen advertising, despite its often-acknowledged ephemeral nature, is an utterly robust phenomenon - robust or persistent in regard to the objects, screens, and practices of screen advertising. It is this persistence of screen advertising that this chapter wishes to draw attention

3 Jay Newell, Charles T. Salmon, and Susan Chang, 'The Hidden History of Product Placement', Journal of Broadcasting \& Electronic Media (December 2006): 575-594, here 577. See also Jane Gaines, 'From Elephants to Lux Soap: The Programming and "Flow" of Early Motion Picture Exploitation', The Velvet Light Trap 25 (Spring 1990): 29-43; Patrick Vonderau, 'Kim Novak and Morgan Stairways: Thinking about the Theory and History of the Tie-in', in Films That Sell: Moving Pictures and Advertising, ed. Bo Florin, Nico de Klerk, and Patrick Vonderau (London and New York: Palgrave, 2016), 209-220. 
to. It is a remarkable robustness or persistence that, curiously, goes hand in hand with an equally remarkable ephemerality of screen advertising.

\section{Object Lessons: Process Films and/as Travelogues}

Process films display a trajectory from raw material to consumable good. This trajectory enacts, as Tom Gunning has argued, a basic narrative of industrial capitalism. ${ }^{4}$ This narrative was largely prefigured by other media that preceded film, such as lantern slide shows, photography, and printing, which helps explain why the process film as a category or genre, if you will, counts among the earliest and most persistent types of industrial film. At the same time, it was a common and popular genre in early cinema. As Frank Kessler and Eef Masson have emphasized, many of the generic markers of early process films originated outside the context of industrial organization and often predated the systematic use of film by the industry. ${ }^{5}$ In fact, these films were part and parcel of the repertoire of popular entertainment culture. Pathé, for example, included process films under the name of scènes (d'art et) d'industrie in its company distribution catalogues in the early 1900 , ${ }^{6}$ and the German trade press started to advertise them as Industriebild (industrial view) in $1907 .{ }^{7}$ In the United Kingdom, the genre was usually called 'industrial moving pictures'. ${ }^{8}$ In the United States, Ernest E. Dench, a journalist and self-proclaimed expert in motion pictures, used the term 'industrialog' in 1916 to describe a type of film that portrays 'the process by which certain goods are manufactured', ascertaining that the industrialog was the most common type of advertising film in the us. ${ }^{9}$ The genre is highly formulaic

4 Tom Gunning, 'Before Documentary: Early Nonfiction Films and the "View" Aesthetic', in Uncharted Territory: Essays on Early Nonfiction Film, ed. Daan Hertogs and Nico de Klerk (Amsterdam: Stichting Nederlands Filmmuseum, 1997), 9-24, here 17.

5 Frank Kessler and Eef Masson, 'Layers of Cheese: Generic Overlap in Early Non-Fiction Films on Production Processes', in Films That Work: Industrial Film and the Productivity of Media, ed. Vinzenz Hediger and Patrick Vonderau (Amsterdam: Amsterdam University Press, 2009), 75-84, here 75 .

6 Ibid., 77.

7 Martin Loiperdinger, 'Early Industrial Moving Pictures in Germany', in Films That Work, ed. Hediger and Vonderau, $65^{-73}$, here 65 .

8 Ibid.

9 Ernest A. Dench, Advertising by Motion Pictures (Cincinnati: Standard Publishing Company, 1916), 47. For a larger discussion of Dench's book and early advertising in the us, see Yvonne Zimmermann 'Advertising and Film: A Topological Approach', in Films That Sell, ed. Florin, de Klerk, and Vonderau, 21-39. 
with conventionalized components, among them a workers-leaving-thefactory scene that, in many process films, precedes or replaces the scene of joyful consumption. Production, packaging, and dispatch are the core features of process films, whereas the extraction of raw material, workers leaving the factory, and consumption can be found in varying combinations.

Scholars such as Martin Loiperdinger, Jennifer Lynn Peterson, and others have pointed to the similarities of process films and travelogues. ${ }^{10}$ Tom Gunning has summarized the two types of films under the category of 'view films', for they both organize a number of single views within a larger, multi-shot logic of exposition. But while films that tour and display locations present space and place as a series of views, films about activities and processes, according to Gunning, obey a temporal rather than a spatial logic of organization and follow 'a more determinate sequential logic of transformation.'. 'Gunning's observation is certainly correct, but, as Milcherzeugung in der Schweiz illustrates, process films do follow a specific spatial logic as well, and perhaps even more so than travelogues, in that they display a travel from an often distant, certainly traditional, agricultural, and typically 'exotic' place to modern and industrialized sites of production and to Western urban bourgeois spaces of consumption. The trajectory depicts the value chain of a product, which goes in one direction only. A returning traffic to the spaces of raw material extraction is not provided. The step-by-step transformation of raw materials into consumable goods is not only presented as a process but also as a civilizational progress from raw to refined. From an ideological point of view, process films are not innocent, but like travelogues, are deeply imbricated in ideas of colonialism, imperialism, and consumption - consumption of landscapes, people, products, and images.

If we consider a film like Milcherzeugung in der Schweiz not in isolation, but as part of a larger programme, more correspondences between process films and travelogues surface, for they had a similar place in the short film programmes in early cinema, which were characterized by a variety format. Charles Musser describes the place of non-fictional films in the programme as follows:

These films, if they were shown in 1912 when one-reel or occasionally two-reel fiction films dominated, must often have served as pauses between fictional

10 See Martin Loiperdinger, 'Early Industrial Moving Pictures in Germany', in Films That Work, ed. Hediger and Vonderau, 65-73; Jennifer Lynn Peterson, Education in the School of Dreams: Travelogues and Early Nonfiction Film (Durham, NC and London: Duke University Press, 2013). 11 Gunning, 'Before Documentary', 15. 
narratives, allowing audiences to recover from one story and prepare for another. They kind of ease the transition from one fictional narrative to another. Perhaps a succession of story films may have been considered too abrupt. Of course, the nonfiction films also undoubtedly served a simple industrial function of allowing the spectator to sort of regroup. ${ }^{12}$

The humorous last scene in Milcherzeugung in der Schweiz, for example, may have perfectly eased the transition to a burlesque film. In this sense, non-fictional films such as travelogues and process films were interstitials or 'in-betweens' that helped manage transitions between fictional films. As further research presented in this book illustrates, being 'in between' is a typical place for moving image advertising within programme structures across different media institutions (cinema, network television, out-of-home screens), and stitching together different forms of intermittent movements into a flow is its typical function (see 'Advertising and the Apparatus'). Also, from a broader institutional perspective, screen advertising is characterized by being 'in between' different institutions (see Vonderau's chapter 'Advertising as Institution'). Searching for a framework to explain advertising's relation to moving pictures and 'cinema proper', Patrick Vonderau has proposed an understanding of screen advertising as 'para-sited cinema'. The 'para-' refers to screen advertising's being 'over and above, in and out of cinema'. This is to stress that screen advertising does not exclusively belong to this or that social space, but moves in between, 'borrowing from the different logics or cultural series that constitute cinema as an open system.'13

This borrowing or appropriation of different logics or cultural series is 'the favoured procedure of all advertising discourse', as Jane Gaines has put it, ${ }^{14}$ and that certainly holds true for process films. Gaines argues that forms of product placement in motion pictures evolved out of a tradition of circus and freewheeling stunts. ${ }^{15}$ Process films however, insofar as they share characteristics with early product placement practices, did not originate primarily in the entertainment business and the circus, but instead are rooted in the encyclopaedia tradition of the eighteenth- and nineteenth-century pedagogy of visual education. Like travelogues, process films provided what Peterson has called 'instructive entertainment' - namely, a form of attraction that

\footnotetext{
12 Comment by Charles Musser in Nonfiction from the Teens, ed. Daan Hertogs and Nico de Klerk (Amsterdam: Stichting Nederlands Filmmuseum, 1994), 29.

13 Patrick Vonderau, 'Introduction: On Advertising's Relation to Moving Images', in Films That Sell, ed. Florin, de Klerk, and Vonderau, 13.

14 Gaines, 'From Elephants to Lux Soap', 31.

15 Ibid., 40.
} 
'packaged didactic intentions as an aesthetic commodity'. ${ }^{6}$ This somewhat uneasy relation between dazzlement and knowledge, according to Gunning, marks the experience of modern visuality, including the contemporary cinema of attractions. ${ }^{17}$ Taking the 1904 St. Louis World Fair as his example, Gunning describes the new visual culture as

a new faith in the power of visual knowledge; a conception of the world itself as a consumable picture, imaged through the collapse of space and time; and an aggressive visual address aimed at dazzling the viewer with a new control over the gaze. ${ }^{18}$

More than travelogues, process films make these features of modern visual culture visible in that they offer explicit images of consumable goods for visual consumption. They are not only presenting the world as a consumable image, they are overtly about consumption, thus rehearsing the protocols of real-life consumption. In that sense, process films are almost reflexive. If travelogues deliver instructive entertainment, process films provide branded instructive entertainment; if travelogues are object lessons, process films are branded object lessons.

\section{Screen Culture, Consumer Culture, and (Un-)Branded Content}

If Milcherzeugung in der Schweiz can tell us any thing about screen advertising and the transformation of screen cultures, it is first of all that moving image advertising cannot be reduced to what for decades has been the epitome of advertising, the TV commercial. In her research on advertising after the network era in the United States, Amanda D. Lotz accounts for the emerging post-network norm, which includes, in addition to the 30 -second ad, multiple advertising strategies such as product placement, integration, branded entertainment, and sponsorship. ${ }^{19}$ To assume that these forms are totally new is obviously wrong, but to consider them as reappearing is equally incorrect, for they have never been absent. They may have been elsewhere, beyond the institutions of classical cinema and television, and

\footnotetext{
16 Peterson, Education in the School of Dreams, 2.

17 Tom Gunning, 'The World as Object Lesson: Cinema Audiences, Visual Culture and the St. Louis World Fair, 1904', Film History 6 (1994): 422-444, here 427.

18 Gunning, 'The World as Object Lesson', 441.

19 Amanda D. Lotz, The Television Will Be Revolutionized (New York: New York University Press, 2007), 153 .
} 
for a long time also beyond scholarly attention. With the digital turn, the emergence of networked and social media, the proliferation of digital screens, and the proclamation of the 'post-cinema' and 'post-television' era, screen advertising has multiplied as well as diversified and now comes in new shapes, formats, and scales. However, in their basic structure, some of these forms and strategies have been utterly robust - product placement being a case in point. As process films illustrate, there have been efforts to efface boundaries between content and advertising and attempts to turn advertising into content and content into advertising since the beginning of moving images. Seen in this light, screen advertising does not appear as a weak and ephemeral object and practice, as is often claimed, but on the contrary as an extremely robust one.

If I underline the robustness or persistence of screen advertising, as other contributions in this book do (see the 'Introduction', for instance), it is not to argue for a discontinuity of historical change between, let's say, 1909 and today's digital multimedia and convergence culture. Instead, while acknowledging the persistence of screen advertising in transformative media cultures, the authors of this book advocate for a downsized, localized analysis of screen advertising that takes into account historical peculiarities, which has also been termed the 'sited-ness' of moving images, that is, to quote Gregory A. Waller, 'the varied and historically specific ways that motion pictures have been put to a host of different uses across a wide range of locations well beyond the commercial movie theatre. ${ }^{20}$ This is to say that the 'robustness' of screen advertising had historically specific, localized appearances, and needs be studied as such.

With its strategy to provide instruction together with entertainment, and to brand both, Milcherzeugung in der Schweiz is an example of how entertainment, instruction, and advertising were found together in early cinema. Thus, the film stands as much for a new mass media culture as it does for a new commercial culture. However, cinema and moving images were never outside of commercial culture, but have rather been part and parcel of it from the very beginnings. Or, as Musser has put it, 'Audiences may have routinely paid good money to be entertained, informed or even instructed; but many of these films were implicitly - and sometimes explicitly - serving an advertising or promotional agenda'. ${ }^{21}$ Examining the

20 Gregory A. Waller, 'International Harvester, Business Screen and the History of Advertising Film', in Films That Sell, ed. Florin, de Klerk, and Vonderau, 40-53, here 40.

21 Charles Musser, 'Early Advertising and Promotional Films, 1893-1900', in Films That Sell, ed. Florin, de Klerk, and Vonderau, 83-90, here 83. 
subjects produced at Edison's Black Maria film studio and/or distributed by the Edison Manufacturing Company in the late nineteenth century from the angle of advertising, Musser concludes that most films become a form of advertising or publicity for someone, something, or somewhere. The forms that he describes include advertising films explicitly made for open-air advertising, but which were occasionally screened in theatrical and other settings (such as Admiral Cigarette [1897] or Dewar's Scotch Whisky [1898], both can presently be seen on YouTube); product placements and sponsoring; various examples of criss-crossing mutual endorsements of variety performers, Edison, and the kinetoscope; and direct forms of selfpromotion - the latter strategy introduced by the Lumière brothers whose films endorsed themselves, their family, their customers, their factory, and, most importantly, their new device, the Cinématographe Lumière. In the era of an emergent consumer society, Edison's early films embody a dialectical tension, according to Musser, in that they both act as a new commodity form and promote other kinds of services and commodities: 'In a multiplicity of ways, the motion-picture industry was intensively engaged in the commodification of culture from its earliest years. ${ }^{22}$

This entanglement of entertainment culture and advertising was, however, by no means a specific feature of the us film industry, but was also part and parcel of European visual culture. It is noteworthy that the concessionaires for the Cinématographe Lumière in England, Germany, and Switzerland were a variety performer (Félicien Trewey); a sales manager of Stollwerck Bros \& Co, Germany's leading chocolate manufacturer before World War I (Ludwig Stollwerck); and the Swiss importer of Sunlight Soap, manufactured by British Lever Brothers (François-Henri Lavanchy-Clarke). Trewey, Stollwerck, and Lavanchy-Clarke were all involved in the entertainment industry, and all drew on the commercial and promotional potential of the Cinematographe in the service of their pre-existing businesses. It was most probably Stollwerck's interest in automated candy vending machines that brought him to mechanical entertainment. Similar motives led Lavanchy-Clarke to co-found, together with Stollwerck, Georges Demenÿ's Société générale du Phonoscope (1892-1895). ${ }^{23}$ In March 1895, Stollwerck opened the first

22 Ibid., 89.

23 Roland Cosandey, 'Lavanchy-Clarke, François-Henry', in Encyclopedia of Early Cinema, ed. Richard Abel (London and New York: Routledge, 2005), 373. For a detailed account, see Martin Loiperdinger and Roland Cosandey, eds., 'L'Introduction du Cinématographe en Allemagne: De la case Demeny à la case Lumière: Stollwerck, Lavanchy-Clarke et al., 1892-1896', Archives, no. $5^{1}$ (November 1992): 16. On Trewey, see John Barnes and Stephen Herbert, 'Félicien Trewey', in Who's Who of Victorian Cinema, http://www.victorian-cinema.net/trewey (last accessed 5 April 2021). 
Kinetoscope parlour in Germany, and in March 1896, he bought the German rights to the Cinématographe Lumière. The first film screening began in Cologne one month later. ${ }^{24}$ As Loiperdinger's research into Stollwerck's business with living pictures has shown, Stollwerck's motivation to invest in the Cinématographe Lumière was to provide an additional popular attraction to his new branch, the permanent exhibition of entertainment machines such as Edison's phonograph and kinetoscope and machines for stereoscope images. The aim was to entice both business partners interested in buying machines as well as a broad audience fascinated by the pleasure the machines offered. In this way, Stollwerck used the Cinématographe Lumière as a side business that enriched the patron's machine exhibitions and promoted the 'modern' image of the company - and as such, if indirectly, also enhanced Stollwerck's main business, the selling of chocolate. ${ }^{25}$

In a somewhat similar vein, Lavanchy-Clarke obtained the rights to exploit the Cinématographe Lumière in Switzerland with the aim to promote Sunlight products. As Roland Cosandey and Jean-Marie Pastor have shown, the Swiss subjects recorded in the Catalogue Lumière (and filmed for the most part by cameraman Constant Girel), mainly derive from this concession. The first film screenings took place on the occasion of the Swiss national exposition in Geneva on 6 May 1896 in the Palais des Fées, which was part of the amusement park adjunct to the exhibition. ${ }^{26}$ Remarkably, from a total of 199 films shot with the Cinémathographe Lumière and deposited in France in 1979 by Lavanchy-Clarke's grandson Jack W. Lavanchy, about forty are not listed in the Catalogue Lumière. ${ }^{27}$ The reason for their absence is that they are either home movies or directly linked to promotional activities. Interestingly enough, there are some explicit promotional views that do figure in the Catalogue, among them Laveuses (Laundresses, also known as Washing Day in Switzerland) discussed in my chapter 'Advertising's Self-Reference'. There are other examples such as Défilé du 8e Bataillon (Deployment of the $8^{\text {th }}$ Battalion; my translation), Vue Lumière no. 316 , shot in Lausanne at Place St François in 1896. This film, which is less than a minute long, depicts the deployment of a battalion marching from the left background of the frame to the right, the left foreground lined with

24 Martin Loiperdinger, 'Stollwerck, Ludwig', in Encyclopedia of Early Cinema, ed. Abel, 612-613, here 612 .

25 Martin Loiperdinger, Film \& Schokolade. Stollwercks Geschäfte mit lebenden Bildern (Frankfurt and Basel: Stroemfeld, 1999).

26 Roland Cosandey and Jean-Marie Pastor, 'Lavanchy-Clarke: Sunlight \& Lumière, ou les debuts du cinématographe en Suisse', Equinox, no. 7 (June 1992), 9-27, here 13.

27 Ibid., 24. 


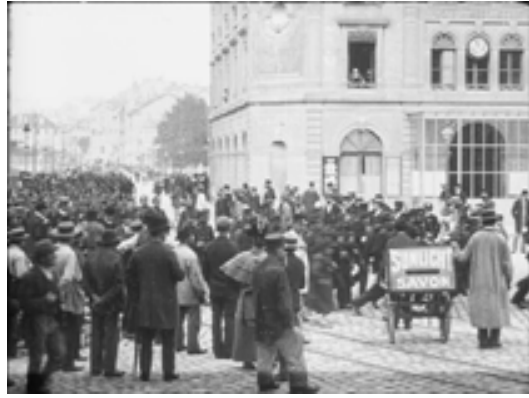

Figure 1.16: Screenshot from Défilé du $8 e$ Bataillon, vue Lumière, 1896.

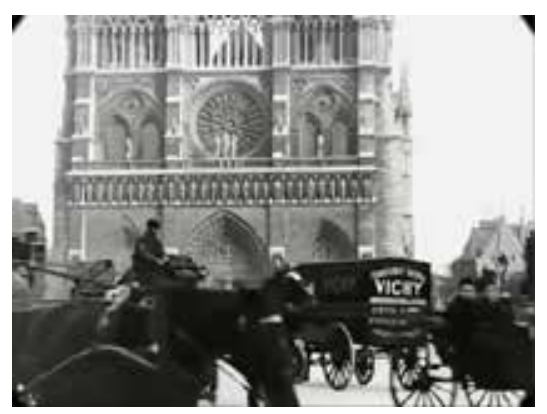

Figure 1.17: Screenshot from Parvis de NotreDame, vue Lumière, 1986.

spectators. A third of the way through the film, a man enters the scene from the right, pulling a handcart that displays a panel reading 'Sunlight Savon' (Sunlight soap). With the cart, Lavanchy-Clarke himself makes a short entrance, thus 'signing' the view, as was typical for him. Two-thirds into the film, the cart is in place, eye-catching and impossible to ignore the space in front of the sign is not crowded, so the spectator has a clear view of it. It is hard to imagine a blunter product placement. According to Newell, Salmon, and Chang, product placement in mass media began with the beginnings of motion-picture projection in the mid 189os. In their historical account on product placement, Lavanchy-Clarke figures as the first to use this strategy. ${ }^{28}$ Whether he was the first is less important than recognizing that he was definitely not the only one. It suffices to refer to Parvis de Notre-Dame shot on 25 October 1896 (Vue Lumière no. 691), ${ }^{29}$ in which a horse-drawn carriage with prominent advertising for Vichy on the back crosses the image in a diagonal from the right foreground to the centre middle ground, right in front of the cathedral.

Clearly, moving images and advertising do not have separate histories, for hardly any films at that time can be understood outside advertising financing practices. In particular, advertising was much more prominent in early cinema than written sources suggest. Musser's comment on Edison's advertising practices is also pertinent in Lavanchy-Clarke's case: 'What is striking is the way in which such signing went unacknowledged in catalogue

28 Newell, Salmon, and Chang, 'The Hidden History of Product Placement', 575-594.

29 https://catalogue-lumiere.com/parvis-de-notre-dame/ (last accessed 5 April 2021). The film is accessible on YouTube: https://www.youtube.com/watch?v=2eXu7IMM-yQ (last accessed 5 April 2021). 
descriptions' $3^{0}$ This practice of effacing traces of advertising in written documents has contributed to the fact that product placement's past is a 'hidden history', as Newell, Salmon, and Chang have put it. ${ }^{31}$ In this sense, screen advertising is at the same time persistent and ephemeral. Or, to put it differently, the ephemeral nature of screen advertising has obscured its robustness. From a methodological perspective, this instance hints at the necessity of combining, wherever possible, discourse analysis on cinema and advertising in specialist publications and the general press (a method that has taken off, especially in the United States, with the extensive digitization of relevant magazines) with textual analysis. This is to argue that the emergence of new, and for certain purposes extremely useful, digital research methods does not make established analytical methods such as close readings, individual and serial analysis, and heuristics superfluous, but that it provides an extension of the historiographical toolbox, which works best if tools are used together in a meaningful manner.

\section{Cross-Branding Film, Consumer Culture, and National Economies}

Lavanchy-Clarke's moving images advertised both Sunlight's laundry soap and Lumière's technological novelty, the Cinematographe. Milcherzeugung in der Schweiz advertises the Bear Brand and the corporation that produces it, the Bernese Alps Milk Company (BAMG), to international audiences, for company and brand names are in English throughout the film. We do not know whether BAMG actively commissioned the film from Pathé or whether Pathé initiated the production and BAMG paid for it (in whole or in part), for there are no archive materials that illuminate the case.$^{32}$ It is also not known whether BAMG used the film for its own promotional activities

30 Musser, 'Early Advertising and Promotional Films, 1893-1900', 88.

31 Newell, Salmon, and Chang, 'The Hidden History of Product Placement', 575-594.

32 Email correspondence with Tanja Aenis, archivist at Nestlé Historical Archives, Vevey, 21 September 2018. Nestlé took over BAMG in 1971, which was then part of the Ursina-Franck group. No company archive exists. The Dorfmuseum alter Bären (Village Museum Old Bear - an old tavern) in Konolfingen has preserved a large number of company documents, but they are tacit about Milcherzeugung in der Schweiz. As a side note, BAMG achieved its breakthrough in 1895, three years after it was founded, when it succeeded in producing an exportable unsweetened condensed milk, the Bärenmarke. On the company history, see Christoph Zürcher, 'Berneralpen Milchgesellschaft', in Historisches Lexikon der Schweiz / Dictionnaire historique de la Suisse / Dizionario storico della Svizzera, 16 Sepember 2010, http://www.hls-dhs-dss.ch/textes/d/D42024. php (last accessed 5 April 2021). 
(although comparable cases would suggest this). As the title indicates, Milcherzeugung in der Schweiz not only advertises a specific company and brand but also a country. As Kessler has outlined, it was a production strategy at Pathé to make films, whether fiction or non-fiction, that are distinguishable by national characteristics, through the use of folkloristic national stereotypes. Hence the highlighting of stereotyped markers of Switzerland such as the traditional costumes of the farmers, the alpine landscape, and cows. This was also probably the motivation to make a film about a milk product and include both 'milk' and 'Switzerland' in the title. Milcherzeugung in der Schweiz uses the same strategies of imagery to brand the film 'Swiss' as Herstellung von holländischem Käse / Comment se fait le fromage de Hollande (The Production of Dutch Cheese, 1909) uses in the opening scenes to brand the film as 'Dutch'. It is in the openings that process films resemble place films the most, because they adopt the visual rhetoric of travelogues as well as their pragmatics to not only substitute for real travel but also encourage real travel. In that sense, early process films helped shape stereotypical ideas about the world and promoted not only companies and brands but also nations as travel and tourist destinations.

At the same time, Milcherzeugung in der Schweiz is a Pathé brand product, which brings us back to cinema and popular entertainment. The film's opening title card announces 'Farbenkinematographie von Pathé Frères' (Colour cinematography by Pathé Frères; my translation), typed in a saturated yellow on a black background that sets the standard for all of the title cards to come. It announces Pathécolor, a stencil-colouring procedure that Pathé patented in 1905 and that was often combined with tinting and toning, as is the case here (for tinting, at least). There were rivalling colour procedures at the time, such as Kinemacolor and Chronochrome (also known as Gaumontcolor), but these techniques required a special projector or were to be seen only in Paris. Not so for Pathécolor, which was widely shown for over 20 years. ${ }^{33}$

Retracing advertising strategies of movie production companies before 1915, Richard Abel has noticed that distinctive trademarks such as George Méliès's 'star', Kleine Optical's doubly circled K, and Pathé's French cockerel 'tinted red on its film prints' appeared as early as 1902, followed shortly by Vitagraph's and Biograph's trademarks. ${ }^{34}$ According to Abel, Pathé was the

33 Mariann Lewinsky, 'Grand Tour of the World in Colour: A Guide to the DVD Set', in I Colori Ritrovati: Kinemacolor e altre magie / Kinemacolor and Other Magic, ed. Mariann Lewinsky and Luke McKernan, DVD booklet (Bologna: Edizioni Cineteca di Bologna, 2017), 28-31, here 29.

34 Richard Abel, 'From Pathé to Paramount: Visual Design in Movie Advertising to 1915', in The Image in Early Cinema: Form and Material, ed. Scott Curtis, Philippe Gauthier, Tom Gunning, and Joshua Yumibe (Bloomington: Indiana University Press, 2018), 78-93, here 80. For a more 

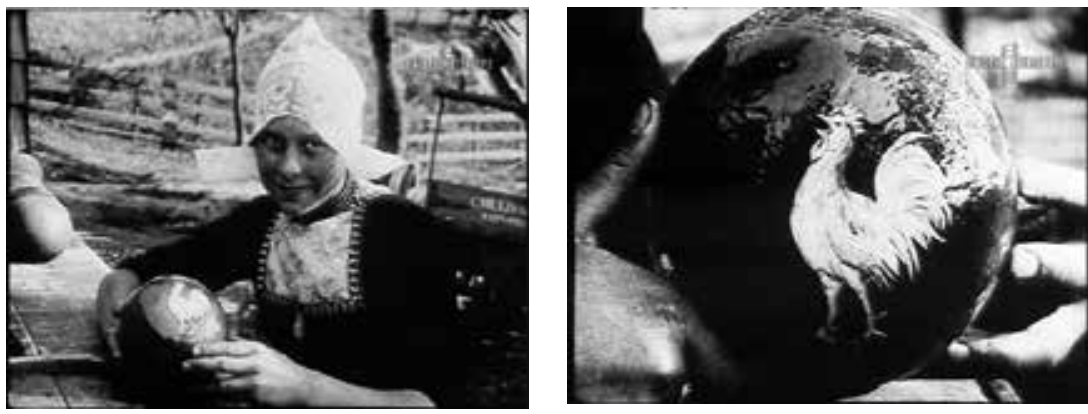

Figures 1.18-1.19: Screenshots from Herstellung von holländischem Käse (Pathé Frères, 1909).

first company to place ads in American daily press, in 1908. The ads were designed to look like film title cards and intended to persuade the public that good moving picture theatres would use only 'pictures with the well-known little red rooster' trademark. ${ }^{35}$

Pathé also found creative ways to promote its red rooster trademark in black-and-white films, as Herstellung von holländischem Käse illustrates. While this process film does not advertise particular cheeses or cheese brands, instead portraying the making of cheese as an artisanal production process, it does prominently stage the industrial scale of cheese production, sales, and international export. ${ }^{36}$ The last title card 'Cheese for export (Painted red)' announces shots that depict two women in costumes who colour wheels of cheese for international export and one woman in a close-up who takes great care to paint something onto some cheese. This something turns out to be, as we discover when she turns the cheese and, with a smile, looks directly into the camera - Pathé's (supposedly red) rooster. The final shot is a full-screen image of a wheel of cheese with a cockerel on it. Abel describes the Pathé red rooster as a kind of 'supersalesman' for the company's films as they travelled the globe, and he holds that Pathé was probably the first film producer 'to use the trademark much like the American companies selling packaged soaps or cereals: it forged a direct link to consumers' ${ }^{37}$ This illustrates how Pathé films were advertised as brand products.

detailed account, see Richard Abel, The Red Rooster Scare: Making Cinema American, 190o-1910 (Berkeley, Los Angeles, and London: University of California Press, 1999).

35 Pathé ad in Chicago Sunday Tribune (5 April 1908): 3.2, quoted in Abel, 'From Pathé to Paramount', 82.

$3^{6}$ On the generic status of the film, see the discussion in Kessler and Masson, 'Layers of Cheese', $75^{-84 .}$

37 Abel, The Red Rooster Scare, 18-19. 
Pathé adhered to this promotional strategy when cinema converted to sound and Pathé-Natan, France's largest production company at the time, advertised the fidelity of Pathé sound films just as much as it advertised Renault and the French automobile industry in a 1934 Pathé journal such as L'Automobile de France, which was dedicated 'To the Glory of the French Industry' (my translation), as one of the opening title cards indicates. With sound being very much a central thematic focus of the film, Pathé presents itself as part of this national industry whose grandeur the film praises..$^{8}$ In fact, as Stéphanie Salmon has retraced, Pathé had already adopted the national emblem of France, the cockerel, as the trademark for the company by 1898 , when Pathé invested in the phonograph and the rooster was used to advertise the sound device with the words 'Je chante haut et clair' (I sing with a high and clear voice; my translation). ${ }^{39}$ With the conversion to sound, Pathé could prove its ability to deliver on this early advertising claim also in cinema. From this perspective, Milcherzeugung in der Schweiz is an early example of Pathé's long-term strategy to cross-brand and cross-merchandise entertainment products with consumer goods, while at the same time putting films in the service of national stereotypes, identities, and economies.

\section{Advertising and Paid Placement versus Non-Paid Placement}

Some scholars have suggested distinguishing advertising from other promotional forms by drawing a distinction between paid placement the defining feature of advertising) and non-paid placement. While it is evident that paid placement is a marker for advertising intentions, there are myriad examples of non-paid placements that are equally made for advertising purposes - viral ads are among the latest examples. BAMG may or may not have paid for the production of Milcherzeugung in der Schweiz; it certainly did not pay for its placement in commercial cinemas. The film figured in the Pathé catalogue, which indicates that it was for sale and rent to cinema

$3^{8}$ The film circulates on the internet and can be found here, for example: http://louisrenault. com/2015/12/23/automobilefrance2808/ (last accessed 5 April 2021). On the film (if not on Pathé's cross-branding in particular), see Alain P. Michel, Travail à la chaîne: Renault $1898-1947$ (Boulogne-Billancourt: Editions ETAI, 2008), 108-115; Alain P. Michel, 'On the Cover: An Image mise en abyme', Technology \& Culture (October 2008): 967-973. On Pathé and the conversion to sound in France, see Charles O'Brien, Cinema's Conversion to Sound: Technology and Film Style in France and the U.S. (Bloomington: Indiana University Press, 2005).

39 See the advertisement in Stéphanie Salmon, Pathé: A la conquête du cinéma 1896-1929 (Paris: Edition Tallandier, 2014), illustration no. 9, n.p. 
owners worldwide. This means that the latter would pay for the placement of a film such as Milcherzeugung in der Schweiz - a film that cross-promotes two companies, two brands, and two countries - and endorses an underlying ideology of capitalism, colonialism, and consumption. To exclude such films from studies on moving image advertising would make it difficult if not impossible to acknowledge the variety and complexity of advertising objects, screens, and practices over time.

In the United States in the mid 1910s, however, advertising films, including process films, were a supplement to the regular programme, which meant that companies and other advertisers paid for the placement of their films. ${ }^{40}$ Whether the placement of moving image advertising was paid for depended not so much on the advertising rhetoric intrinsic to the moving images, the filmic text, but on the placement, that is on the specific places in which they were screened. This again illustrates the 'sited-ness' of screen advertising and the necessity to adopt a localized analytical perspective that takes into account the specific exhibition contexts and particular uses of moving images. In the case of process films, as with other films also considered of educational value, whether fictional or non-fictional, the very same films would circulate in a variety of institutional contexts and were framed in manifold ways, as the growing body of research of useful cinema has shown. Some exhibitions were paid placements; others were not. Whether films served mainly promotional, entertainment, or educational purposes depended as much (if not more) on the off-screen framing of the exhibition than on the on-screen presence of markers. Corporations would often donate process films to distributors of classroom films, which rented such films to schools. Thus, they made educational institutions seeking instruction pay for advertising. ${ }^{41}$ Hence, advertising has been the price for access to information and entertainment not only since the rise of online media cultures, but since the earliest days of moving images.

At the same time, advertising films turned into educational films on their trajectory to the classroom, which is to say that the generic identity of such films was not fixed, but flexible, and would change with changing institutional exhibition contexts. ${ }^{42}$ This is another facet of the persistent,

40 See Dench, Advertising by Motion Pictures, 47. See also Jeremy Groskopf, 'Profit Margins: Silent Era Precursors of Online Advertising Tactics', Film History 24, 1 (2012): 82-96.

41 See, for example, Yvonne Zimmermann, ed., Schaufenster Schweiz: Dokumentarische Gebrauchsfilme 1896-1964 (Zurich: Limmat, 2011).

42 This could be read as a response to Waller's question about how much generic identity depends on when and where a film is exhibited. See Waller, 'International Harvester', 5o. On the question of genre and screen advertising, see Yvonne Zimmermann, 'Advertising and 
yet at the same time ephemeral nature of screen advertising; other aspects of this quality are the performative character of off-screen framings in specific exhibitions through live commentary, discussions, and give-aways, for example. The filmic text, then, was and is but a potential (or, metaphorically speaking, a projection): a potential for entertainment, education, and advertising. When screened, all potentials are actualized. But which ones are accented depend on the specific exhibition event.

\section{Colour, High-End Advertising, and Colonial Imagery}

The last section of this essay leaves exhibition and turns to Milcherzeugung in der Schweiz as a film in itself and to its colour aesthetics. In the first decade of the 190os, Pathé was the leading film production company internationally. This dominance was largely due to the success of Pathe's colouring processes and practices. ${ }^{43}$ Pathé was particularly known for its stencilling, which, according to Joshua Yumibe, reached a technical high point in terms of precision for the cutting of the stencils and for the dye-application process by the end of the decade. ${ }^{44}$ While in the 'cinema of attractions' years leading up to 1907, colour was mainly seen in the trick and fairy genres, Pathé expanded production of colour films to historical dramas, films d'art (literary adaptations), and non-fiction - among them most prominently travelogues and process films. Yumibe has observed that, with these changes, Pathé 'crafted its colouring styles to be subdued, genteel, and less saturated, a stylistic emphasis that resonated better with the emerging norms of unobtrusive narration, for light, pastel hues could be deployed in ways less distracting to the eye'. ${ }^{45}$ This stylistic development is certainly the case for fictional genres, if not for travelogues and process films in general, because the latter continued to bear typical features of the cinema of attractions such as the exhibitionist gesture of display, the importance of the act of looking, direct

Film: A Topological Approach', in Films That Sell, ed. Florin, de Klerk, and Vonderau, 21-39. A useful genre taxonomy according to distribution and exhibition contexts is suggested by Ralf Forster, Ufa und Nordmark: Zwei Firmengeschichten und der deutsche Werbefilm 1919-1945 (Trier: Wissenschaftlicher Verlag Trier, 2005), 27-44.

43 See Abel, The Red Rooster Scare.

44 Joshua Yumibe, 'The Color Image', in The Image in Early Cinema, ed. Curtis, Gauthier, Gunning, and Yumibe, 142-150, here 144. See also Joshua Yumibe, Moving Color: Early Film, Mass Culture, Modernism (New Brunswick: Rutgers University Press, 2012).

45 Yumibe, 'The Color Image', 144. 
audience address, and frequent looks into the camera. ${ }^{46}$ Colour was part of this stylistic repertoire, for early cinema's applied colours added a special attraction to films shot in black and white. Films would be sold in black and white or in colour, with colour being a selling point and commercial factor. Colour films were expensive, but they stood out in the programmes and functioned as a means of drawing attention - a function that is key to advertising and also a main feature of the cinema of attractions. Or, as Daan Hertogs has put it, 'stencilled nonfiction films are the ideal tool for demonstrating that a spectator cannot afford to miss anything going on on the screen'. ${ }^{47}$ Underlining the role of colour for the conception of advertising in the emerging mass consumer culture, Gunning holds that colour was not only a means to draw attention to advertisements themselves, but also a way of 'endowing consumer goods with an indefinable surplus to their use value'. ${ }^{48}$ With its sophisticated colour scheme combining stencilling and tinting, Milcherzeugung in der Schweiz was a prestige product for both Pathé and BAMG, with colour testifying to the quality of the moving picture and of what it depicts: BAMG's condensed milk.

On a reflexive conceptual and methodological note, taking a film with appealing aesthetic features and high production values as an example is an approach typical not only in film historiography but also in studies on screen advertising. With its focus on remarkable advertising campaigns, funny self-referential commercials, stylish advertisements made by people with a name in the film industry and/or the art scene, and on discourses that intersect with prominent figures from acknowledged academic fields such as the documentary and the avant-garde, the present book is no exception. The observations that John Ellis has made in his work on interstitials and how they define television programmes may serve as a valid justification for this approach: holding that product differentiation (as the main function of interstitials) needs both explanation and aestheticization of products, commercials and interstitials in general produce a sense of beauty (with the help of greater production values) that makes them stand out from the

46 The features of the cinema of attractions are described in Tom Gunning, 'The Cinema of Attractions: Early Film, Its Spectator and the Avant Garde', in Early Cinema: Space Frame Narrative, ed. Thomas Elsaesser (London: British Film Institute, 1990 [1986]), 56-62.

47 Daan Hertogs, 'Attention Essential: Coloured Nonfiction Films from the 1910s', in Uncharted Territory, ed. Hertogs and de Klerk, 97-103, here 101.

48 Tom Gunning, 'Colorful Metaphors: The Attraction of Color in Early Silent Cinema', Fotogenia: Storie e teorie del cinema, Il colore nel cinema 1 (1995): 249-255,

https://archivi.dar.unibo.it/files/muspe/wwcat/period/fotogen/numo1/numerold.html (last accessed 5 April 2021). The essay is also published in Living Pictures 2.2 (2003): 4-13. 
rest of the TV programme. In the elegance and perfection of their images, interstitials, according to Ellis, 'present a vision of television as it could be [...] if only it were even more costly that it already is'. ${ }^{49}$ To stand out, cinema and TV commercials generally have had more production resources per minute than feature fiction films or Tv broadcasts. So did Milcherzeugung in der Schweiz, in comparison to longer narrative black-and-white films in the programmes.

The academic predilection for the exceptional in advertising, for innovative advertising campaigns, advanced aesthetics, and the signature of acknowledged authors is paired with little interest in the overwhelming number of upfront, dull, boring, and often annoying commercials that we come across anywhere and any time. This tendency to neglect the large quantity of neither outstanding nor particularly poor, but mediocre advertisements stands in opposition to our ordinary experiences, which are characterized by average advertising objects and practices that all seem to look more or less the same. The robust mediocrity - another facet of the robustness of advertising - and the sameness of moving image advertising and advertisements could be a productive epistemic field to complement studies on the exceptional and outstanding, and provide new insights especially into phases of continuity and stability in the history of advertising media and screen cultures at large. Other related and as yet largely neglected areas are local advertising as well as semi-professional and amateur advertising objects, screens, and practices, which are often hard to mine due to their small production and dissemination scale. They may have left little trace individually, but taken as a whole, these advertisements and advertising practices have been extremely widespread, and therefore make a pertinent object for further studies.

On a final note, I would like to return to high-end and large-scale advertising, and to Milcherzeugung in der Schweiz. Discovering the richness of early colour films at a workshop at what was then the Netherlands Film Museum in Amsterdam in 1995, early cinema scholars were baffled by the 'disorderly order' of colouring practices, because they could not find colour codes that applied to all films..$^{0}$ They noticed that some production companies such

49 John Ellis, 'Interstitials: How the "Bits in Between" Define the Programmes', in Ephemeral Media: Transitory Screen Culture from Television to YouTube, ed. Paul Graine (London: Palgrave Macmillan, 2011), 59-69, here 99.

$5^{0}$ See Daan Hertogs and Nico de Klerk, eds., Disorderly Order: Colours in Silent Film (Amsterdam: Stichting Nederlands Filmmuseum, 1996). 
as Film d'Arte Italiana and Pathé stencilled more or less systematically for some genres, but also found that, in addition to the codes, there was a fair amount of free variation. ${ }^{51}$ Process films produced by Pathé were among those genres that were highly standardized also in regard to colouring, based on my observations of examples researched in film and corporate archives or made available on DVD, and Milcherzeugung in der Schweiz is a case in point. In early cinema, both hand-colouring and stencilling were at times used to heighten the realism of the moving images, but more often than not, they were applied for aesthetic and artistic purposes, thus eschewing naturalism in favour of sensationalism and adding a painterly and metaphorical quality to the images..$^{52}$ In the pastoral opening of Milcherzeugung in der Schweiz, the stencilling draws attention to certain bucolic and visually attractive aspects such as the traditional costumes, the cowbell shimmering in bronze, and the trees blooming in pastel purple and white. In other words, all the features that refer to an idea of a pristine mountain place and a traditional way of working and living are highlighted through colouring. With the milking of the cow, the film switches from stencilling to tinting (a procedure in which black-and-white film strips were soaked in dye) and presents the scene in saturated sepia. Another noticeable change in colour occurs in the next view, which marks the dispatch of the milk to the factory and which is tinted in blue, the coded blue-for-night or dawn colour, which serves as a temporal marker in this case. From here onwards, the film is tinted. The testing of the milk as well as scenes of the indoor production processes are in sepia, whereas the two scenes (not following each other) that depict women wrapping cans are in pastel purple. The making of shipping cases - men's work - is presented in sepia again. Obviously, different working spaces are coloured differently according to gender. Finally, the loading of the goods on a freight train is tinted in blue again, signalling both an outdoor activity in contrast to the indoor manufacturing processes and a time shift.

Overall, the film takes great care to change colours frequently in order to provide visual diversity. At the same time, the colour changes work as attention-grabbers. Colours are a visual effect to attract viewer attention, and at the same time function as temporal and spatial markers in that they orient the viewer to time of day and to locations, including gendered work spheres. They have both a crucial aesthetic and a narrative function. In the final scene, the film changes from tinting to stencilling again. This colour change emphasizes the switch in rhetoric and audience address 
from indirect to direct, appellative address, and the change of sphere from production to consumption.

My contention is that in using stencilling for the extraction of raw material and the consumption of the final product - that is, for views that depict either the traditional and the 'exotic' or the pleasures of consumption - and in using tinting for the presentation of industrial production processes, Milcherzeugung in der Schweiz is an exemplary case for process films in Pathécolor around 1910. To support this thesis, I would like to turn to another process film produced by Pathé in 1909, Le Thé: culture, récolte et préparation industrielle (Tea: Cultivation, Harvesting, and Industrial Processing). ${ }^{53}$ Le Thé uses strikingly similar colour codes - namely, stencilling for the cultivation and harvesting of tea leaves in the opening scenes of the film, tinting for the industrial processing of raw material, and stencilling for the consumption of tea. Stencilling is both a marker for the exotic - the cultivation of tea in foreign territories (here, most probably in the former Ceylon, now Sri Lanka) - and for the exquisite - the preparation and consumption of tea in a bourgeois Victorian home. What Le Thé makes clearer than Milcherzeugung in der Schweiz is the fact that process films in the period of early cinema were aesthetically and ideologically proponents of a visual culture that was deeply entangled with ideas of colonialism and 'the exotic other', and colouring played a part in this. Stencilled non-fictional films are not 'uninterpreted fact', as Hertogs has underlined. Instead,

the filmmakers in the studios coloured the images and in doing so made choices. During the process of colouring, the filmmakers "interpret" the world that they see on the film (which they do not necessarily need to be familiar with in reality) $[. .$.$] in an arbitrary manner. { }^{54}$

Like travelogues, process films address Western audiences, and they depict the world from a Western-centric perspective. Those who look at - and consume - the films are 'us'. Those who are looked at are 'them', 'the other' - 'other' in terms of habits, customs, race, and 'level of development', staged for the camera as 'exotic' visual attraction. Stencilling highlights the act of looking and depicts the 'imperial gaze' as a legitimate form of 'just looking', which, ideologically, is of course never innocent. At the same time, stencilling

53 The film is included in the DVD I Colori ritrovati: Kinemacolor e altre magie / Kinemacolor and Other Magic, ed. Mariann Lewinsky and Luke McKernan (Bologna: Cineteca di Bologna, 2017).

54 Hertogs, 'Attention Essential', 103. 

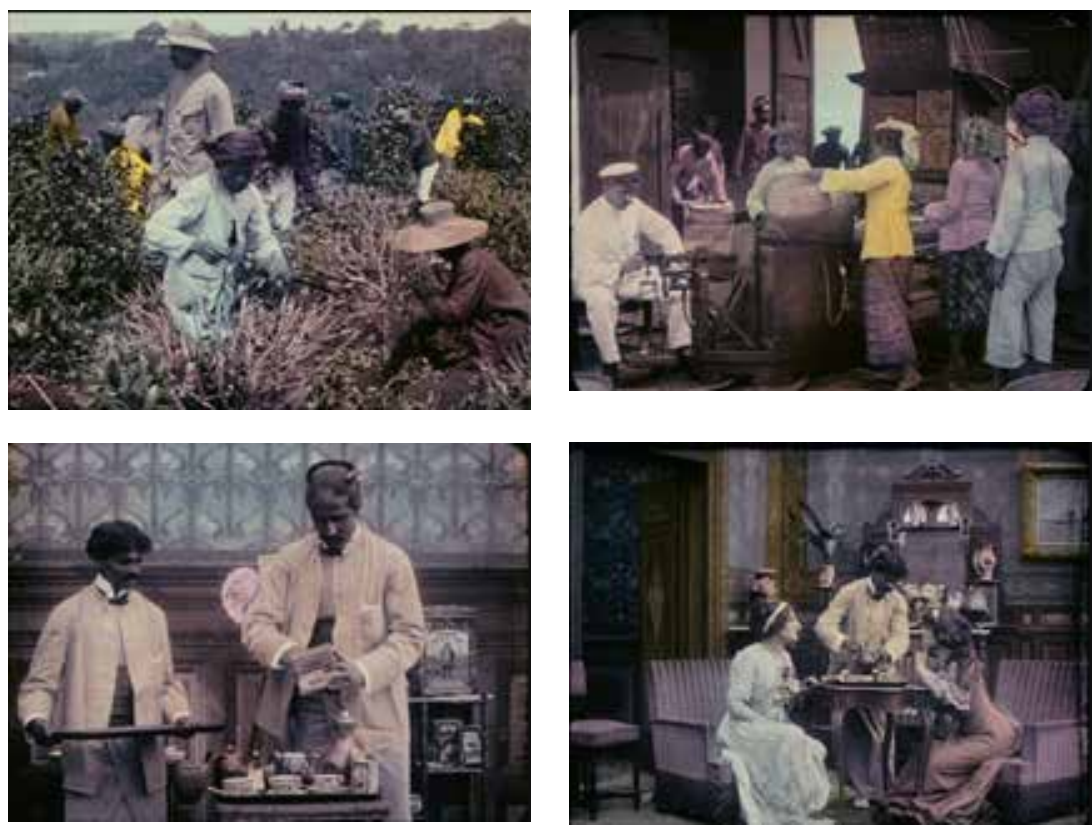

Figures 1.20-1.23: Screenshots from Le Thé: culture, récolte et préparation industrielle (Pathé Frères, 1909).

produces notions of racial difference and white supremacy alongside gender and class sensibilities. This not only accounts for process films that display raw material extraction in colonies overseas, but also for Milcherzeugung in der Schweiz, which, with the help of colour, depicts the Bernese Oberland as an 'internal colony'. The concept of internal colonialism emerged in the late 1950s with the intention to generate attention to structural, political, and economic inequalities between regions within a state. According to Stephen Howe, internal colonialism refers to geographically close, yet culturally distinct locations (distinct in terms of language, physical appearance, technological development, etc.) and is used to describe the separation between centre and periphery, between metropole and colony. ${ }^{55}$ With the same narrative, aesthetic, rhetoric, and ideological use of colouring, Le Thé and Milcherzeugung in der Schweiz produce cultural differences. They depict

55 Stephen Howe, Empire: A Very Short Introduction (New York: Oxford University Press, 2002). On the current place of the concept of internal colonialism in postcolonial theory and social theory, see Paulo Henrique Martins, 'Internal Colonialism, Postcolonial Criticism and Social Theory', Revue du MAUSS permanente (11 August 2018), http://www.journaldumauss. net/./?Internal-Colonialism-Postcolonial-Criticism-and-Social-Theory (last accessed 5 April 2021). 
both the former Ceylon and the Bernese Oberland as traditional, primitive, and exotic 'other', distinct from an industrialized, modern, urban, and consumerist way of living. Process films not only adopted and propagated this perspective, they also helped legitimize and naturalize it. In this sense, Milcherzeugung in der Schweiz draws attention to advertising screen cultures' entanglement with colonial and imperial perceptions of the world.

\section{An Outlook Instead of a Conclusion}

Process films are particularly fascinating because they do not hide their imperial ideology, but rather exhibit it explicitly. The sheer visibility of white supremacy, racism, and segregation opens these films for postcolonial critique. Process films addressed cinema audiences worldwide and provided a common base of shared experiences of screen advertising in cinemas. This common base of collective experiences has been surprisingly stable throughout the history of screen advertising, if we think of television's decades-long ability to aggregate dispersed (national) publics, coupled with its predominance as advertising medium. With an emerging industry for big data capture, increasingly personalized advertising, and audience fragmentation, these shared public reference points disaggregate progressively in contemporary digital media cultures. Along with this trend, advertisements as objects of study also disaggregate, since researchers can no longer count on a common arena of advertising objects, audiences (designed as clear-cut target groups), and experiences..$^{6}$ While I have stressed the robustness of objects, screens, and practices of moving image advertising and highlighted continuities rather than changes, big data mining, personalization in advertising, and algorithms that customize advertisements according to gender, race, and domicile ${ }^{57}$ appear to be instantiations of a transition phase that represent significant methodological challenges. Such new forms of advertising produce new forms of racism and segregation that are far less visible, and thus less recognizable, examinable, and criticizable than ever before. Notwithstanding whether we want to see this as a genuinely

$5^{6}$ On personalized advertising and big data with regard to democracy, see Nick Couldry and Joseph Turow, 'Advertising, Big Data, and the Clearance of the Public Realm: Marketers' New Approaches to the Content Subsidy', International Journal of Communication 8 (2014): 1710-1726. 57 See Joseph Turow, The Daily You: How the Advertising Industry Is Defining Your Identity and Your Worth (New Haven: Yale University Press, 2012). See also, if less specific to advertising, Safiya Umoja Noble, Alogrithms of Oppression: How Search Engines Reinforce Racism (New York: New York University Press, 2018). 
new development in screen advertising or, as I would argue, as a new level of robustness - and ephemerality - it is a development that calls for our critical attention.

\section{Bibliography}

Abel, Richard. 'From Pathé to Paramount: Visual Design in Movie Advertising to 1915.' In The Image in Early Cinema: Form and Material, edited by Scott Curtis, Philippe Gauthier, Tom Gunning, and Joshua Yumibe, 78-93. Bloomington: Indiana University Press, 2018.

Abel, Richard. The Red Rooster Scare: Making Cinema American, 1900-1910. Berkeley, Los Angeles, and London: University of California Press, 1999.

Barnes, John, and Stephen Herbert. 'Félicien Trewey.' In Who's Who of Victorian Cinema, http://www.victorian-cinema.net/trewey. Last accessed 5 April 2021. Cosandey, Roland. 'Lavanchy-Clarke, François-Henry.' In Encyclopedia of Early Cinema, edited by Richard Abel, 373. London and New York: Routledge, 2005.

Cosandey, Roland, and Jean-Marie Pastor. 'Lavanchy-Clarke: Sunlight \& Lumière, ou les debuts du cinématographe en Suisse.' Equinox, no. 7 (June 1992): 9-27.

Couldry, Nick, and Joseph Turow. 'Advertising, Big Data, and the Clearance of the Public Realm: Marketers' New Approaches to the Content Subsidy'. International Journal of Communication 8 (2014): 1710-1726.

Dench, Ernest A. Advertising by Motion Pictures. Cincinnati: Standard Publishing Company, 1916.

Ellis, John. 'Interstitials: How the "Bits in Between" Define the Programmes.' In Ephemeral Media: Transitory Screen Culture from Television to YouTube, edited by Paul Graine, 59-69. London: Palgrave Macmillan, 2011.

Forster, Ralf. Ufa und Nordmark: Zwei Firmengeschichten und der deutsche Werbefilm 1919-1945. Trier: Wissenschaftlicher Verlag Trier, 2005.

Gaines, Jane. 'From Elephants to Lux Soap: The Programming and "Flow" of Early Motion Picture Exploitation.' The Velvet Light Trap 25 (Spring 1990): 29-43.

Groskopf, Jeremy. 'Profit Margins: Silent Era Precursors of Online Advertising Tactics.' Film History 24, no. 1 (2012): 82-96.

Gunning, Tom. 'Before Documentary: Early Nonfiction Films and the "View" Aesthetic.' In Uncharted Territory: Essays on Early Nonfiction Film, edited by Daan Hertogs and Nico de Klerk, 9-24. Amsterdam: Stichting Nederlands Filmmuseum, 1997.

Gunning, Tom. 'Colorful Metaphors: The Attraction of Color in Early Silent Cinema.' In Fotogenia: Storie e teorie del cinema, Il colore nel cinema 1 (1995): 249-255, https://archivi.dar.unibo.it/files/muspe/wwcat/period/fotogen/numo1/numerold.html. Last accessed 5 April 2021. 
Gunning, Tom. 'The Cinema of Attractions: Early Film, Its Spectator and the AvantGarde.' In Early Cinema: Space Frame Narrative, edited by Thomas Elsaesser, 56-62. London: British Film Institute, 1990 [1986].

Gunning, Tom. 'The World as Object Lesson: Cinema Audiences, Visual Culture and the St. Louis World Fair, 1904.' Film History 6 (1994): 422-444.

Hertogs, Daan. 'Attention Essential: Coloured Nonfiction Films from the 1910s.' In Uncharted Territory: Essays on Early Nonfiction Film, edited by Daan Hertogs and Nico de Klerk, 97-103. Amsterdam: Stichting Nederlands Filmmuseum, 1997.

Hertogs, Daan, and Nico de Klerk, eds. Disorderly Order: Colours in Silent Film. Amsterdam: Stichting Nederlands Filmmuseum, 1996.

Hertogs, Daan, and Nico de Klerk, eds. Nonfiction from the Teens. Amsterdam: Stichting Nederlands Filmmuseum, 1994.

Howe, Stephen. Empire: A Very Short Introduction. New York: Oxford University Press, 2002.

Kessler, Frank, and Eef Masson. 'Layers of Cheese: Generic Overlap in Early NonFiction Films on Production Processes.' In Films That Work: Industrial Film and the Productivity of Media, edited by Vinzenz Hediger and Patrick Vonderau, 75-84. Amsterdam: Amsterdam University Press, 2009.

Lewinsky, Mariann. 'Grand Tour of the World in Colour: A Guide to the DVD Set.' In I Colori Ritrovati: Kinemacolor e altre magie / Kinemacolor and Other Magic, edited by Mariann Lewinsky and Luke McKernan, DVD booklet, 28-31. Bologna: Edizioni Cineteca di Bologna, 2017.

Loiperdinger, Martin. 'Early Industrial Moving Pictures in Germany.' In Films That Work: Industrial Film and the Productivity of Media, edited by Vinzenz Hediger and Patrick Vonderau, 65-73. Amsterdam: Amsterdam University Press, 2009. Loiperdinger, Martin. Film \& Schokolade: Stollwercks Geschäfte mit lebenden Bildern. Basel: Stroemfeld, 1999 .

Loiperdinger, Martin. 'Stollwerck, Ludwig.' In Encyclopedia of Early Cinema, edited by Richard Abel, 612-613. London and New York: Routledge, 2005.

Loiperdinger, Martin, and Roland Cosandey, eds. 'L'Introduction du Cinématographe en Allemagne: De la case Demeny à la case Lumière: Stollwerck, Lavanchy-Clarke et al., 1892-96.' Archives, no. $5^{1}$ (November 1992): 16.

Lotz, Amanda D. The Television Will Be Revolutionized. New York: New York University Press, 2007.

Martins, Paulo Henrique. 'Internal Colonialism, Postcolonial Criticism and Social Theory.' Revue du MAUSS permanente (11 August 2018), http://www.journaldumauss.net/./?Internal-Colonialism-Postcolonial-Criticism-and-Social-Theory. Last accessed 5 April 2021. 
Michel, Alain P. 'On the Cover: An Image mise en abyme.' Technology \& Culture (October 2008): 967-973.

Michel, Alain P. Travail à la chaîne: Renault 1898-1947. Boulogne-Billancourt: Editions ETAI, 2008.

Musser, Charles. 'Early Advertising and Promotional Films, 1893-1900.' In Films That Sell: Moving Pictures and Advertising, edited by Bo Florin, Nico de Klerk, and Patrick Vonderau, 83-9o. London and New York: Palgrave, 2016.

Newell, Jay, Charles T. Salmon, and Susan Chang. 'The Hidden History of Product Placement.' Journal of Broadcasting \& Electronic Media (December 2006): 575-594.

Noble, Safiya Umoja. Alogrithms of Oppression: How Search Engines Reinforce Racism. New York: New York University Press, 2018.

O'Brien, Charles. Cinema's Conversion to Sound: Technology and Film Style in France and the U.S. Bloomington: Indiana University Press, 2005.

Peterson, Jennifer Lynn. Education in the School of Dreams: Travelogues and Early Nonfiction Film. Durham, NC and London: Duke University Press, 2013.

Salmon, Stéphanie. Pathé: A la conquête du cinéma 1896-1929. Paris: Edition Tallandier, 2014.

Turow, Joseph. The Daily You: How the Advertising Industry Is Defining Your Identity and Your Worth. New Haven: Yale University Press, 2012.

Vonderau, Patrick. 'Introduction: On Advertising's Relation to Moving Images.' In Films That Sell: Moving Pictures and Advertising, edited by Bo Florin, Nico de Klerk, and Patrick Vonderau, 1-18. London and New York: Palgrave, 2016.

Vonderau, Patrick. 'Kim Novak and Morgan Stairways: Thinking about the Theory and History of the Tie-in.' In Films That Sell: Moving Pictures and Advertising, edited by Bo Florin, Nico de Klerk, and Patrick Vonderau, 209-220. London and New York: Palgrave, 2016.

Waller, Gregory A. 'International Harvester, Business Screen and the History of Advertising Film.' In Films That Sell: Moving Pictures and Advertising, edited by Bo Florin, Nico de Klerk, and Patrick Vonderau, 40-53. London and New York: Palgrave, 2016.

Yumibe, Joshua. Moving Color: Early Film, Mass Culture, Modernism. New Brunswick: Rutgers University Press, 2012.

Yumibe, Joshua. 'The Color Image.' In The Image in Early Cinema: Form and Material, edited by Scott Curtis, Philippe Gauthier, Tom Gunning, and Joshua Yumibe, 142-150. Bloomington: Indiana University Press, 2018.

Zimmermann, Yvonne. 'Advertising and Film: A Topological Approach.' In Films That Sell: Moving Pictures and Advertising, edited by Bo Florin, Nico de Klerk, and Patrick Vonderau, 21-39. London and New York: Palgrave, 2016. 
Zimmermann, Yvonne, ed. Schaufenster Schweiz: Dokumentarische Gebrauchsfilme 1896-1964. Zurich: Limmat, 2011.

Zürcher, Christoph. 'Berneralpen Milchgesellschaft.' In Historisches Lexikon der Schweiz / Dictionnaire historique de la Suisse / Dizionario storico della Svizzera, 16, September 2010, http://www.hls-dhs-dss.ch/textes/d/D42024.php. Last accessed 5 April 2021. 